\title{
How Empirical Social Research Gained Ascendancy in Post-War France*
}

\author{
HYNEK JEŘÁBEK** \\ Faculty of Social Sciences, Charles University, Prague
}

\begin{abstract}
Sociology changed significantly in Europe after the Second World War. An interest in research with practical applications began to prevail. This article explains how this transformation came about in France and what contributed to the change. Sociologists at the Sorbonne were the first to actively support the use of an empirical approach in the social sciences. In this connection they invited Paul Lazarsfeld, one of the founders of the Columbia school of sociology, to spend a year at the Sorbonne in 1962. Drawing on archive sources, this article reveals the factors that lay behind the creation of an original three-volume anthology of methodological writings that was the outcome of collaboration between Lazarsfeld and Raymond Boudon. They compiled this anthology in French with the aim of promoting this new research paradigm among social scientists in France. The article examines the structure of this French methodology textbook, analyses the thematic orientation of the articles, and notes different works that were jointly authored by French and American scholars. On a second sabbatical at the Sorbonne in 1967, Lazarsfeld followed up on this publishing activity and further pursued his primary interest - the methodology of data analysis.
\end{abstract}

Keywords: France, Paul Lazarsfeld, Raymond Boudon, Sorbonne, methodology of empirical social research

Sociologický časopis/Czech Sociological Review, 2022, Vol. 58, No. 3: 235-255

https://doi.org/10.13060/csr.2021.044

\section{Introduction}

This article focuses on Paul Lazarsfeld's work in France between 1948 and 1970 and the influence of his methodology in France and in Europe after the Second World War. The methodology of empirical social research that was developed by the Columbia school of sociology came to be the most frequently used model of sociology in the post-war United States and Western Europe. Historians ex-

\footnotetext{
* Work on this article was supported by the Czech Science Foundation, grant no. 1813807S.

** Direct all correspondence to: Hynek Jeřábek, Institute of Sociological Studies, Faculty of Social Sciences, Charles University, U Kř́iže 8, 15800 Prague 5, Czech Republic, e-mail: hynek.jerabek@gmail.com.
}

(C) Sociologický ústav AV ČR, v. v. i., 2022

(C) Author, 2022 
plained the increasing dominance of empirical social research as due to the interests of government agencies or American foundations, or as due to the competition between members of the emerging post-war generation of scholars and the representatives of a traditional approach to sociology with a philosophical or theoretical focus. Another factor behind the ascendancy of the empirical model, and one that especially played a role in French sociology, was the competition between the Marxist orientation of left-wing sociologists, led by Pierre Bourdieu, and a smaller group of scholars who were more influenced by Paul Lazarsfeld, and in this group we find such figures as Jean Stoetzel, Raymond Boudon, André Davidovitch, and Bernard-Pierre Lécuyer.

In this article I set out to trace the work of Lazarsfeld and his colleagues and doctoral students and identify this work as one of the important factors explaining the post-war transformation of European sociology. I focus on Paul Lazarsfeld's collaborations with representatives of French post-war sociology and examine what influence the Columbia school of sociology had in France, and what role was played in this process by UNESCO and, in particular, the Sorbonne in Paris.

A general attempt to explain how the 'Columbia research model' came to be dominant in American and European sociology up until the late 1960s is provided in Stephen P. Turner and Jonathan H. Turner's monograph The Impossible Science. An Institutional Analysis of American Sociology [Turner and Turner 1990]. Turner and Turner cite Paul Lazarsfeld's research projects as an example of the kind of research that foundations were keen on funding [ibid.: 101]. According to this source, foundations changed 'the rules of the academic hierarchy' in a direction away from abstract academic sociology to a sociology that is of practical use [ibid.: 89]. Another important resource for understanding the place of 'methodological positivism' and Paul Lazarsfeld in post-war sociology is a collective monograph edited by Craig Calhoun [2007]. One chapter in this book is by George Steinmetz, who argues emphatically that '... during the 1950s and well into the 1960s (and perhaps beyond), methodological positivism prevailed in the leading sociology journals, in the most widely used textbooks and methodology books, in the top departments, and in the tastes of the relevant funding agencies' [Steinmetz 2007: 339-340]. According to Steinmetz [ibid.: 341]: 'Lazarsfeld's Bureau of Applied Social Research constituted a center of methodological expertise and research in positivist spirit.'

Lazarsfeld's students and successors offered another explanation for the changes that occurred in sociology after the Second World War. James Coleman [1982: 1] wrote: 'Paul Lazarsfeld was one of those rare sociologists who shaped the direction of the discipline for the succeeding generation.' Allen Barton, another of Lazarsfeld's colleagues, praised a positive view of Paul Lazarsfeld's idea for the University Institute for Applied Social Research [Barton 1982], which he argued was the tool that was necessary to transform survey methods for use in the social sciences, adapting them to the analysis of social processes [ibid.: 19]. 
In Europe Lazarsfeld probably made his biggest mark in France. Although he lived in the United States after emigrating from Europe in 1935, he spent a lengthy period of time in Paris twice before the war: the first time was the year he spent there after completing his university studies (1924/1925) and the second was in 1927, when he spent several months there with his first wife, Marie Jahoda. After the war he frequently travelled to Paris and Europe. He visited France many times on multiple occasions. He became involved in activities organised by UNESCO, headquartered in Paris; he co-founded the International Sociological Association (ISA) in Paris and in Oslo; and he lectured in Norway in the winter semester of 1948. In 1962/1963 and 1967/1968 he twice taught for an entire academic year at the Sorbonne.

French social scientists regarded Lazarsfeld's empirical social research and his positivist approach as an import from the United States. At the same time, most French sociologists, and especially those in the group headed by Pierre Bourdieu, were in principal familiar with the positivist approach. Pierre Bourdieu's team, however, embraced a different conception of positivism, a different approach to quantification. They developed their own school, which followed and built on Emile Durkheim's pre-war positivism.

The majority of sociologists in France were highly critical of the type of sociology practised in post-war America. The primary reasons for this were ideological and political. Most Frenchs sociologists were politically left-wing and rejected this 'American import'. Many of them were strongly influenced by Marxist thought.

Pierre Bourdieu, for example, wrote the preface to the French translation of Marienthal, in which he focused on the study's qualitative ethnographic findings and cited examples of the effects of mass unemployment, poverty, and disillusionment as a reaction to the situation, and in which he explained these findings from the perspective of Marxist theory. He wrote: '... what is discovered or uncovered is the sense of abandonment, desperation, and even absurdity that engulfs people who have suddenly been deprived not just of work and a salary but also of any social purpose in life and are thereby confronted with the naked truth of their situation' [Bourdieu 1982: i]. ${ }^{1}$

While on the one hand they were impressed by American methodological know-how, on the other hand they rejected it as 'right-wing ideology'. Lazarsfeld was therefore not in an easy position, and his ideas were not going to be automatically accepted. His supporters - Jean Stoetzel and Raymond Boudon - were in the position of a minority in French sociology.

\footnotetext{
${ }^{1}$ Here is the original French version: '... ce qui se livre ou se trahit, c'est le sentiment de délaissement, de désespoir, voire d'absurdité, qui s'impose à l'ensemble de ces hommes soudain privés non pas seulement d'une activité et d'un salaire, mais d'une raison d'être sociale et ainsi renvoyés à la vérité nue de leur condition’ [Bourdieu 1982: i].
} 
Michael Pollak, in a paper evaluating Paul Lazarsfeld's work, adds a more concrete explanation to these general statements [Pollak 1980]. In response to the question '... which factors contributed to his [Lazarsfeld's] key role in reorienting social science research in Europe after the war?' [ibid.: 158], Pollak wrote: 'In the early 1960s Lazarsfeld's enterprise was thriving. His conception of sociology, increasingly in demand by state bureaucracies and business, dominated the discipline in most European countries' [ibid.: 173]. He described the motivation behind these processes as follows: 'European scholars interested in the institutionalization of empirical research sought legitimacy and prestige for their strategic efforts to reinforce their power in the universities. This converged with the interests of the American scientific community in increasing its international prestige; it also attracted the large foundations, in particular Ford and Rockefeller, with their longstanding interest in foreign affairs.' [ibid.: 171] Michael Pollak, however, characterised French social scientists as people who were afraid of tempting that American foundations and programmes strived to control the European scientific institutions [ibid.: 171-173].

A slightly different assessment of Paul Lazarsfeld's contribution to French sociological thought was offered by Stefanie Averbeck, who compared sociological ideas and communication theories in France and Germany. She described the academic cultures in these two countries and the differences between them: in Germany empirical social research was influenced by 'the "classical" US-American tradition', while France is dominated by the tradition of 'les sciences de l'information et de la communication', which are rooted in semiotics and cultural theories [Averbeck 2008: 1-3].

In the introduction to an anthology of Lazarsfeld's writings, Raymond Boudon wrote: 'By the 1960s, Lazarsfeld had become a dominant figure in the social science. Perhaps only Talcott Parsons enjoyed a similar standing ... Lazarsfeld's reputation was acknowledged not only in the United States, but in Europe as well, particularly where he had been directly active in the development of social research' [Boudon 1993: 5]. Then he described and evaluated Lazarsfeld's activities and his instrumental role in the collaboration between Columbia University in the United States and the Sorbonne in France [ibid.: 10-12, 22-24]. But this was only one of the many ways in which French scholars responded to Lazarsfeld. Some French scholars even said that the Boudon-Stoetzel cluster was a marginal group in post-war French sociology.

Lazarsfeld had friends and colleagues in Paris and many doctoral students at the Sorbonne. Together with Raymond Boudon he published three anthologies of methodological writings in French. Raymond Boudon also published a collection of Lazarsfeld's studies in 1970 in a book that was only published in French and was never released in English [Lazarsfeld 1970]. Evidence of the important role Paul Lazarsfeld played in the French social sciences is that he was awarded an 'honorary degree of Sorbonne University' and was the first American sociologist to receive such an honour. 


\section{Lazarsfeld's first post-war activities in Paris}

The first lecture Lazarsfeld gave in Paris (of which there are archive records) was intended for political scientists and took place in October 1948. The lecture presented the results of Lazarsfeld's research on the American Presidential elections and the methods used in the research. The organiser of this event, François Goguel, invited Lazarsfeld on behalf of the Fondation Nationale des Sciences Politiques (Sciences Po). ${ }^{2}$ Lazarsfeld sent a response almost immediately, on 27 July. The subject of the lecture was one that would have certainly interested political scientists and Lazarsfeld definitely had something to say about the subject. His book The People's Choice had been published not long before (the first edition in 1944 and the second edition in 1948) and the book was known in Paris. Sciences Po was (and is) a fully-fledged, self-governing research university that specialises in the social-economic sciences and the humanities. ${ }^{3}$ Active members of the university, François Goguel and his colleague Henri Mendras, helped to introduce Columbia scholars to French readers [see Chenu 2001] - for example, Mendras translated Merton's Social Theory and Social Structure [ibid.: 106].

Before this visit to Paris Lazarsfeld had been actively involved in the work of UNESCO. ${ }^{4}$ A meeting of representatives from this international organisation was planned in Paris in October 1948, so Lazarsfeld arranged the date of his lecture to coincide with that event. Lazarsfeld was willing to give the lecture in French, and in doing so he demonstrated his interest in the French public. This also allowed the organisers to invite a larger number of political scientists to attend the lecture. In his response Lazarsfeld wrote that he would come from Oslo and that he would like to arrange his visit to Paris and his lecture around 'the date of the UNESCO meeting which I might want to participate in'..$^{5}$ Lazarsfeld arrived in Paris in the middle of October and spent around two weeks in Paris, and he probably stayed in the country until the end of October. In addition to giving a lecture, he took part in the meeting of the social sciences section of UNESCO that was being held and from archival resources we know that he and the sociologist delegates from the United States and various European countries who attended this meeting reached a preliminary agreement on establishing the International Sociological Association (ISA). The first, inaugural congress of the ISA was held on 5-10 September 1949 in Oslo, Norway [Thue 2006: 283, 353].

In the years that immediately followed, Lazarsfeld was busy with various obligations in the United States. In 1950 the BASR research institute at Columbia University ran into financial difficulties [see Barton 1982: 27] and Paul Lazarsfeld

\footnotetext{
2 A letter from F. Goguel to Paul F. Lazarsfeld in Paris dated 22 July 1948.

${ }^{3}$ https://transsol.eu/people/consortium/sciences-po-paris/.

${ }^{4}$ UNESCO, the international organisation for education, science, and culture, was founded under the United Nations in 1946 and its headquarters were established in Paris.

${ }^{5}$ A letter from Paul F. Lazarsfeld to F. Goguel in New York dated 27 July 1948.
} 
and Robert K. Merton worked together to transform BASR into a training centre that would teach graduate students how to conduct empirical social research. The failure of this proposal led Lazarsfeld to draw up and then implement (in the years 1952 to 1954) a project that had as its main aim the preparation of a number of important methodological publications with the support of this money. ${ }^{6}$ It was only after this that Lazarsfeld began to take a greater interest in Europe again and both UNESCO and Paris become his 'windows into Europe'.

\section{Jean Stoetzel and Paul Lazarsfeld: the motives for their collaboration}

A key figure involved in Lazarsfeld's time in France was Jean Stoetzel (1910-1987), a French social psychologist who was around ten years younger than Lazarsfeld. He had visited the United States in 1938, in all likelihood with the support of the Rockefeller Foundation. He spent time at Columbia University and while he was in the United States he became acquainted with the public opinion poll model of George Gallup. When he returned to France, Stoetzel founded the first French institute for public opinion research, the private Institut français d'opinion publique (IFOP). During the Second World War, in Vichy France, Stoetzel worked in Bordeaux as a philosophy teacher at a secondary school. In 1942 he began working for the French Foundation for the Study of Human Problems, which was founded by the French physiologist and biologist Alexis Carrel. Stoetzel worked there until the end of the war. He obtained his doctorate in philosophy in Paris at the Sorbonne's Faculty of Philosophy (Faculté des lettres) in 1943. His doctoral adviser was the famous French philosopher and sociologist Maurice Halbwachs [Wikipedia 2021].

Lazarsfeld became acquainted with Stoetzel's current ideas from materials that were published by UNESCO, which Stoetzel contributed to. He met him personally at UNESCO events and ISA congresses, in which both of them participated. ${ }^{7}$ Paul Lazarsfeld and Jean Stoetzel had similar views on the social sciences. They both regarded empirical research as an integral part of their academic fields. Jean Stoetzel was a social psychologist and was one of the first chairs of the World Association for Public Opinion Research (WAPOR), and he founded an institute for public opinion research (in France). Lazarsfeld was one of the founders of the American Association for Public Opinion Research (AAPOR) and was elected its third chair for the 1949-1950 academic year. He published a paper in the very first issue of Public Opinion Quarterly, which was AAPOR's newly launched of-

\footnotetext{
${ }^{6}$ For details on Lazarsfeld's and Merton's plans for a training centre and on the contents and the results of the Planning Project for Advanced Training (PPAT project), see Jerabek [2012: 16-20].

${ }^{7}$ For example, at the 4th Congress of ISA in Milan and Stresa in Italy in September 1959 they presented papers on very similar methodological topics.
} 
ficial journal. His model of sociology moreover had much in common with social psychology.

Lazarsfeld knew Jean Stoetzel's body of work, and surprisingly well. In an article titled 'Public Opinion and the Classical Tradition' that he published in Public Opinion Quarterly in 1957, for example, he cited Stoetzel's dissertation, writing: 'Stoetzel, incidentally, was the first, in his dissertation in France, to stress the relation of history and political science to attitude research.' [Lazarsfeld 1957: 46] In one part of this article he focused on the subject of researching the 'climate of opinion', which shows us how closely he followed the results of Jean Stoetzel's work. This reference also provided evidence of Lazarsfeld's active participation in the work of UNESCO. In the article Lazarsfeld describes the questions that are posed in public opinion polls relating to the differences between classes and groups of the population within a country studied. He presents the following particularly interesting question as an example: 'Does a worker or a business man feel he has more in common with people of the same class in other countries, or with people of a different class in his own country?' [ibid.] And it is here that he makes a reference to a contemporary article by Jean Stoetzel [1953] and writes: 'The general role of such questionnaire items is discussed and exemplified by Jean Stoetzel in an article on the use of polls in social anthropology.' [Lazarsfeld 1957: 46]

Lazarsfeld's work was known in France. Those scholars who were able to read in English, and Stoetzel was one of them, were familiar with The People's Choice and perhaps other work Lazarsfeld had written as well. Lazarsfeld's popularity also benefited from the then recent publication of a new German edition of Marienthal, which until then was almost entirely unknown in the academic world. This second edition was published in 1960 by the Verlag für Demoskopie, the official publisher of the Institute for Public Opinion Research in Allensbach. ${ }^{8}$ French social scientists took note of the methodological reflections that Lazarsfeld formulated in the new introduction he wrote for this study of an unemployed community. In a lengthy article about Lazarsfeld's influence in post-war France that we will refer to relatively frequently below, Giuliana Gemelli [1998: 480] noted: ' '.. the growing general interest in Lazarsfeld's introduction to the re-edition of Die Arbeitslosen von Marienthal published in 1960 in which Lazarsfeld comments favourably on integrating diverse sociological concepts, on the technical sophistication of American sociology, on German phenomenology, and on analysis on the level of strata and classes "à la française".

Jean Stoetzel did not explicitly mention any connection to Lazarsfeld's work, but he shared a conceptual outlook similar to Lazarsfeld's in many respects. Ge-

\footnotetext{
${ }^{8}$ Almost no one knew of the first edition of 'Marienthal' because it was published in Leipzig in 1933 during the time of Hitler's rise to power and it consequently never reached readers. Publication of the second edition was organised thirty years later by Erich Peter Neumann and Elisabeth Noelle-Neumann through the publisher of the Institute for Demoscopy in Allensbach, which they founded after the Second World War.
} 
melli said of Stoetzel's textbook on social psychology (La psychologie sociale, 1963) that '... for him social psychology is a kind of bridge connecting the sociological approach, with its focus on social classes, cultural models, and collective representation, and the psychological approach, with a focus on the internal motivational processes, perceptions, and memorizing' [ibid.: 481]. Stoetzel was an active sociologist after the war, and in 1960 he founded Revue française de sociologie.

Lazarsfeld and Stoetzel had complementary intellectual viewpoints and they also shared similar views on science policy [ibid.]. In the late 1950s and early 1960s, Lazarsfeld developed an extensive project that was designed to capture the history of empirical sociology (in France, England, Germany, and Italy). The first results that he produced in this project were published in Isis review in 1961. In a postscript to this study Lazarsfeld explained the reasons that led him to take up this subject of research [Lazarsfeld (1961) 1982a: 166-167]. Based on concrete examples of the promising beginnings that empirical social research had demonstrated in Germany and elsewhere in Europe, Lazarsfeld reached a general conclusion that was extremely important for the development of collaboration in the field of the social sciences in Europe in the early 1960s: '... Nothing is stranger than the idea often expressed by European colleagues that quantification is a US export endangering their tradition. It is true that when this country [the United States] took over the European empirical research techniques, it did so on a large scale. But the steps by which this came about are little known. Here is a vast area for further inquiry...' [ibid.: 166]. Lazarsfeld realised how much work needed yet to be done before the European and American perspectives on sociology could be brought closer together.

In researching European sources of empirical social research Lazarsfeld primarily sought to identify a trajectory of continuity in the evolution of methodological ideas in the social sciences. The beginnings of the use of empirical data in the work of social scientists in Europe was followed by a second stage in which these efforts and experiences were further developed in the United States, where some useful scientific instruments of social analysis were developed. In the third stage great importance was attached to efforts to apply these instruments back in Europe again.

\section{The role of UNESCO in Lazarsfeld's collaboration on research in France}

Lazarsfeld contributed to the development of UNESCO's activities and played an especially instrumental role in the field of methodology. The expansion of UNESCO's operations into the wider sphere of the social sciences beyond its initial focus on economics occurred within the framework of the 'VIth Section'. The most important long-term project was the 'Mathematics in Social Sciences' programme, which was carried out with the financial support of the Rockefeller Foundation. According to G. Gemelli [1998: 489], ' ... the scientific prestige of this 
initiative was primarily associated with the role that was played in it by Paul Lazarsfeld, James Coleman, Frederick Mosteller ...' and other members of the VIth Section of UNESCO.

In connection with the discussions on this new project within the Social Sciences Section of UNESCO, Lazarsfeld met Fernand Braudel for the first time. Braudel was for Lazarsfeld an important source of support for his ideas and programmes. They shared the view that researchers in the social sciences needed specialised training and they were closely aligned on this issue [ibid.: 488, 490]. It was in the area of training researchers in the applications of mathematics in the social sciences that a group of methodologists managed to succeed at introducing the seminar model throughout the period of the 1960s, starting in 1960. According to the plan that was adopted by UNESCO: 'At the seminars a small group of prominent American social scientists specialised in the field of the applications of mathematics in the social sciences were intended to present the latest developments in this field to a selected group of around 20 young social scientists from universities and research institutes from all over Europe.' [ibid.: 489]

It was in reference to the first of these seminars in 1960 that Lazarsfeld formulated suggestions in a memorandum that he distributed to all the individuals who had been invited to teach the seminars. It is clear from the content of the memorandum that the plan was for the seminar to run for several weeks and that this was de facto a 'summer school'. What is interesting is the kind of questions Lazarsfeld sought to address in his memorandum:

(1) 'Fellowship 9 for Europeans.'

(2) 'Repeated seminars in Europe like the one organized this year. Programs for such a sequence are discussed in a separate memorandum. ${ }^{10}$

(3) 'The position of ... UNESCO officiers ...They are responsible for equalization of knowledge in all countries. ... they should bring mathematics to social scientists in Europe.' [ibid.: 3]

And as a fourth point in the memorandum, Lazarsfeld asked:

(4) '.. what do we need today in the application of mathematics to the social sciences?' And answering his own question, he wrote: '... What is needed is a young generation who are mathematical social scientists by profession. Therefore, a seminar like yours which exposes the participants to a fairly large variety of topics and techniques is appropriate' [ibid.].

\footnotetext{
${ }^{9}$ Financial support for students from Europe.

10 This memorandum, which Lazarsfeld wrote at the UNESCO Seminar on the Use of Mathematics in the Social Sciences in Menthon Saint Bernard, on 1-27 July 1960, is located in the Columbia University Archives: 'MEMORANDUM From: P. Lazarsfeld. The Rare Books and Manuscript Library of Columbia University', Collection Lazarsfeld, box 29, folder UNESCO4, 1960 1-27 July, 4 pages.
} 
Lazarsfeld played an important role in devising the seminars organised within the framework of UNESCO's 6th Section. Lazarsfeld sent out the memorandum sometime in the spring months of 1960. The teachers had been selected and it was necessary to agree on the order in which these instructors would take part and decide on the topics that were to be dealt with in individual blocks of lectures. The text of the memorandum clearly indicates that it was Lazarsfeld who, in the second point of the memorandum, proposed establishing a tradition of seminars on the 'applications of mathematics in the social sciences' so that they could take place on a regular basis. All the parties involved in making the decision accepted the idea of organising the seminars at two-year intervals and in a different European country on each occasion. In the 1960s these summer schools were always organised as a two-week course [Neurath 1979: 59-60]. The first of the seminars took place in the summer of 1960 in France in the mountain resort of Menthon-Saint-Bernard (see footnote 12 for the source of this information).

Training in empirical social research was so important in Lazarsfeld's view that he '...suggested curricula for Enseignement Préparatoire à la recherche Approfondie en Sciences Sociales (EPRASS), a postgraduate course taught at the end of the 1960s at the École pratique des Hautes Etudes in Paris to many young sociologists who made up the first generation to take advantage of a good practical training in empirical research' [Chenu 2001: 106].

\section{Lazarsfeld's first sabbatical at the Sorbonne in Paris (1962/1963)}

There are many reliable sources that refer to the sabbatical year Lazarsfeld spent in Paris in 1962/1963 [e.g. Boudon 1993: 5; Pollak 1980: 173]. ${ }^{11}$ Giuliana Gemelli [1998: 484] said the following about Lazarsfeld's stay in Paris: 'A year after publishing his article in Isis (in June 1961), whereby he initiated a systematic inquiry into the intellectual and historical roots of quantification, Lazarsfeld left for a one-year stay in Paris and thanks to Stoetzel's invitation became a professeur associé at the Sorbonne.'

It was Jean Stoetzel, as head of the department of sociology at the Sorbonne, who invited Lazarsfeld to come and give a series of lectures at the Sorbonne in the early 1960s. Gemelli claimed that this situation initially caused something of 'a minor revolution' because this arrangement looked as though the hiring of Lazarsfeld, a foreign professor, had to be 'paid for' by not hiring a French professor. The post of guest professor had not yet been introduced at the Sorbonne [ibid.]. By 23 January 1961 the Sorbonne was already discussing the possibility of arranging Lazarsfeld to be a guest lecturer. Records from the Sorbonne in-

\footnotetext{
${ }^{11}$ On Lazarsfeld's teaching commitments in Paris Michael Pollak wrote: 'In 1962/63 while teaching at Sorbonne, he took an active part in disputes within the French sociological community, supporting those who opted for a more empirical and applied orientation.' [Pollak 1980: 173]
} 
dicate that: ' $\ldots$ from February 1962 ... the Assembly wanted to enter into cooperation with Professor Paul Lazarsfeld, a professor of sociology at Columbia University. The objective of this cooperation is to advance teaching in social psychology, which is drawing interest from an increasing number of students'. ${ }^{12}$ The Sorbonne had thus expressed its interest, but it was with the help of the American Fulbright programme that Lazarsfeld's visit was actually able to take place, as it provided the funding for Lazarsfeld's stay in Paris to teach at the Sorbonne in the 1962/1963 academic year [Gemelli 1998: 484]. Drawing on archive sources, Gemelli found that the Fulbright Foundation provided the Sorbonne with the financial resources to pay for Lazarsfeld's teaching engagement [ibid.]. According to Gemelli, Lazarsfeld's teaching engagement at the Sorbonne moreover also contributed to Professor Otto Klineberg being appointed a guest professor the year after Lazarsfeld [ibid.].

The classes Lazarsfeld taught at the Sorbonne in 1962/1963 largely dealt with the history of social research. He taught a seminar once a week on the early history of empirical research in the social sciences, especially in Europe. According to Bertrand-Pierre Lécuyer, regular participants in this seminar included Raymond Boudon, André Davidovitch, Francois-André Isambert, Bernard-Pierre Lécuyer, Catherine Boddard, Michel Dion, Jean-Claude Passeron, among others [Lécuyer 2002: 65]. Lazarsfeld was around this time supervising several doctoral students, all of whom were focusing their work on the history of empirical research in Europe. He supervised the work of Anthony Oberschall at Columbia University and at the Sorbonne. Later in the 1960s he was the supervisor for Bernard-Pierre Lécuyer, Terry N. Clark, and Susanne P. Schad at Columbia University. ${ }^{13}$

An extremely important factor behind the development of Lazarsfeld's long-term cooperation with the Sorbonne was that the academic exchange between France and the United States was a reciprocal arrangement. Raymond Boudon spent a year (1960/1961) at Columbia University, as did other French postgraduate students [Gemelli 1998: 485]. After Lazarsfeld returned to New York, Bernard-Pierre Lécuyer went to Columbia University and spent the next two years there (1964-1966) in the Department of Sociology and at BASR, and while he was there he was involved in organising the joint seminar that Lazarsfeld and Merton taught on the history of empirical social research [ibid.].

Lazarsfeld personally helped Raymond Boudon and Joffre Dumazedier to find financial support for their stay, which was then funded by American foun-

\footnotetext{
12 Information drawn from the minutes of a meeting of the Assemblée des professeurs de la Faculté des Letters, on 23 January 1961, signed by A. Aymard. Cited in Gemelli [1998: 484, 500].

${ }^{13}$ I have devoted a separate paper elsewhere to Lazarsfeld's contributions to the history of empirical social research [Jeřábek 2021]. Although this partly relates to cooperation between Lazarsfeld and the Sorbonne, uniting these two subjects would be beyond the scope of a single article.
} 
dations. He also provided important assistance in arranging translations of their works from French into English and getting them published. Lazarsfeld was able to organise this through his ties to American publishers [cf. Gemelli 1998: 485].

This cooperation between highly productive and creative French and American sociologists and methodologists that began in the early 1960s and that benefited both sides continued to yield fruit for many decades. Gemelli has drawn attention to the correspondence that was exchanged between Lazarsfeld and Boudon primarily between 1963 and 1970: '... at a time when Boudon's books translated into English began to be published' [ibid.].

\section{Publication of the three-volume anthology Méthodes de la Sociologie in Paris}

Lazarsfeld's lectures at the Sorbonne won over the first significant supporters and promoters of empirical social research and its methodology in France and increased the amount of interest in this model of sociology. Lazarsfeld's work and strengthening partnership with Raymond Boudon continued to develop successfully in this atmosphere of international transatlantic cooperation. They put together an important new publication: a three-volume anthology of methodological writings in French. This work, which was of fundamental importance for the spread of advanced methods in social research in France, was similar in nature to $L S R{ }_{,}^{14}$ but it was not a translation and instead contained original writings in French that Lazarsfeld and Boudon compiled specifically for this publication. Lazarsfeld, along with Boudon, devoted great effort between 1963 and 1965 to preparing the first and, a year later, the second volume of this methodological compendium for publication in French [Boudon and Lazarsfeld 1965, 1966].

We need to understand how important it was to offer new ideas to French scholars and students of sociology in their native language. The majority of sociologists who were in top positions in France in the 1960s did not share Lazarsfeld's model of empirical sociology and for ideological reasons opposed the import of new methods from the United States. But when Lazarsfeld with Raymond Boudon, with the support of the French Fondation Maison des Sciences de l'Homme, produced a three-volume methodological anthology in French with examples of useful instruments for social research, these writings found their readers. This anthology continues to be used for teaching social-research methodology at universities in France.

Only a small portion of the contents of the French anthology was made up of the original English-language texts from the LSR translated into French. As editors of the work that was being prepared in French, Lazarsfeld and Boudon

${ }^{14}$ The Language of Social Research (LSR) had been published a decade earlier in the United States [Lazarsfeld and Rosenberg 1955]. 
showed enormous motivation and went to great effort to find suitable texts by French authors - methodologists. They had to find the right texts for each volume in French or had to request French scholars to write the texts that were required for this anthology devoted to methodology. Additional texts were found in new methodological publications, usually of American origin, which had been published in the preceding decade, and these chapters and papers were then translated into French. The compendium was planned as a three-volume work collectively titled Méthodes de la Sociologie. Each volume, however, also had its own title that specified what the methodological writings it contained were about.

In the first volume Boudon and Lazarsfeld focused on the initial and very important stage of every empirical social research. They titled the first volume Le vocabulaire des sciences sociales and subtitled it 'Concepts et indices'. This volume was naturally about more than just concepts and indicators. It focused on concepts, indicators, indices, and variables, and on developing variables, and typologies. We know from Lazarsfeld's and Merton's general methodological comments that they, and likely also their students and followers, believed that an important starting point for any research was its 'conceptualisation' and therefore also the consideration given to the concepts deemed to be of significance for a given subject and the connections between them. ${ }^{15}$ This was reflected in the contents of this first volume. The book was published with the support of the French Fondation Maison des Sciences de l'Homme. The foreword to this anthology was written by the person who initiated this French-American collaboration - Jean Stoetzel.

A comparison of the contents, scope, and structure of this first volume in the anthology of methodological writings in French and the LSR, its American counterpart, subtitled A Reader in the Methodology of Social Research and published ten years earlier in the United States in 1955, reveals some similarities between them, but also some surprisingly significant differences:

(1) The French anthology had its own unique contents that was not based on the structure of the LSR. There were plans to publish subsequent volumes and thus there was no need to cover every topic in the first volume. The overall structure of the first book was adapted to fit its subtitle: 'Concepts and Indices'. The introductory section of the first volume was titled 'Géneralités sur la construction des variables' ('The general rules for creating variables'), and it was followed by sections on enumeration indexes, typologies, and parametric indexes. The final section of the volume was devoted to the conceptual interpretation of texts, that is, of qualitative material.

(2) The book was published in French for French social scientists and for sociologists in particular. It was not a 'translation' of the American textbook, LSR, and importantly, it contained original texts written by French scholars.

${ }^{15}$ For a detailed analysis of this subject including references to writings by Lazarsfeld and Merton, see Jerabek [2012: 20-24]. 
(3) The French anthology contained 25 texts, 10 of which were new originals by French scholars, and only 5 were translated texts from the LSR. Several more texts were translated from English, but most were from new literature.

(4) The texts that dealt with typologies, in particular, which were written both by American and French scholars, usefully tied in with each other and represented a good example of French-American collaboration.

(5) There were two texts in this volume of the anthology, each of which was written by a pair of authors, one French and one American. One of these texts was by Jean Stoetzel and Paul Lazarsfeld: 'A Definition of the Intention and the Space of Attributes' (Définition d'intention et espace d'attributs) [Boudon and Lazarsfeld 1965: 189-193], which was written for this publication. The other one was by Raymond Boudon and Paul Lazarsfeld: 'Notes on the Formal Meaning of Ten Indicators' (Remarques sur la signification formelle de deux indices) [ibid.: 224-228]. Boudon and Lazarsfeld built on the observations that were made by two French authors in the chapter that preceded theirs [ibid.: 214-223] and proposed a formal mathematical model to resolve the problem set out by the previous chapters' authors.

The second volume of the French anthology of methodology was published the very next year and was titled L'analyse empirique de la causalité [Boudon and Lazarsfeld 1966]. This volume was devoted to the applications of multidimensional analysis, analyses of deviant cases, and contextual analysis. One of the last chapters published in the volume was by Raymond Boudon and was devoted to the role of individual and collective attributes in this ecological type of analysis ('Propriétés individuelles et propriétés collectives: un problème d'analyse écologique') [ibid.: 191-219]. An interesting feature of this volume was the inclusion of three texts by Émile Durkheim ('Fait individuel et fait social', 'État civil et suicide', 'Suicide et divorce') [ibid.: 37-40, 81-97, 141-151], one by Maurice Halbwachs, and one by Robert K. Merton [ibid.: 57-61; 121-123].

An introductory section titled 'La logique générale de l'analyse' (The general idea of analysis) opens with a text that introduces readers to the principles of multidimensional statistical analysis, and Paul Lazarsfeld selected his own text for this purpose: 'L'Interprétation des relations statistiques comme procédure de recherche' (An interpretation of statistical relations as a research operation) [Boudon and Lazarsfeld 1966: 15-27]. This text can, given his and others' experience in teaching data analysis, be considered the best possible introduction to this subject. Using seven tables of real data over three printed pages he illustrates the strength and robustness of the elaboration model. It shows how the researcher is able to uncover apparent but false relationships and/or discover deeper and truer connections in the data under analysis. This text by Lazarsfeld serves as the opening to this second volume of the anthology.

What was the third volume of the French anthology of methodological writings like? [Chazel, Boudon and Lazarsfeld 1970] We can get some idea just from 
its title: 'L'Analyse des processus sociaux' (An analysis of social processes). This subject area was one of key interest to Paul Lazarsfeld and his co-editors, François Chazel and Raymond Boudon. ${ }^{16}$ This volume mainly contained new texts written in French. It was also the biggest of the three volumes, with the most pages and the largest number of texts. Of the 27 texts it contained, only 4 were from the LSR. The third volume contained 8 texts by French scholars, and 2 of these were written by Raymond Boudon for this anthology. Among these were texts from recent publications by French social anthropologists, historians, and sociologists from the 1960s. Another 15 texts, usually from recent publications by authors writing in English, were written by scholars from the fields of sociology, history, political science, and psychology. The entire thematic spectrum of the social sciences devoted to the study of social processes were representatively covered in this volume. There was also a text by Norwegian sociologist Natalie Rogoff on professional job mobility, the inclusion of which attests to the growing internationalisation of empirical social analyses at that time. The third volume of the anthology also contained a French translation of an important theoretical-methodological article written jointly by Merton and Lazarsfeld, 'L'amitié comme processus social' [ibid.: 249-266], which was first published in English in 1954 with the title 'Friendship as a Social Process' and was not published again until 1982 [Lazarsfeld and Merton (1954) 1982].17

Among the scholars who contributed to the three volumes of the anthology published in French were Lazarsfeld's colleagues, students, and devoted successors in the United States: Edward Suchman, Hans Zeisel, Samuel A. Stouffer, Carl Hovland, Bernard Berelson, Hazel Gaudet, Seymour M. Lipset, Morris Rosenberg, Patricia L. Kendall, Robert, K. Merton, Wagner Thielens, Charles Glock, Elihu Katz, James Coleman, Allen Barton, and Herbert Menzel. We need to remember how few translations there were of American sociological literature into French in the decades after the war. The absence of translations into French is mentioned in a report that looked back on the decades from the 1960s to the 1990s. Alain Chenu [2001: 106] wrote: 'The main Classics of US survey research, by Lazarsfeld, Katz, Stouffer, Blau and Duncan, and Hauser, remain inaccessible to the French reader ...'.

Methodological texts written by French scholars Émile Durkheim, Maurice Halbwachs, Jean Stoetzel, Raymond Boudon, and Claude Goguel were also included in the anthologies. Contributions by younger collaborators of Boudon and Lazarsfeld like André Davidovitch, Viviane Isambert-Jamati, and Francois Simiand were also published. In a sense the three-volume French methodological publication surpassed the LSR on which it was based and that had been pub-

\footnotetext{
${ }^{16}$ Social processes were only the starting point for Raymond Boudon's publications [see Raymond Boudon 2014].

${ }_{17}$ For a discussion of how Merton and Lazarsfeld collaborated on this paper see [Jerabek 2012: 13-16].
} 
lished earlier and served as a source of inspiration and example for this anthology. It is therefore no surprise that two years later Lazarsfeld and two co-authors, Morris Rosenberg and Ann K. Passanella, published a new English-language anthology titled Continuities in the Language of Social Research [Lazarsfeld, Passanella and Rosenberg 1972], in which they explored some subjects more deeply, most notably the application of multi-dimensional data analysis and examples of the applications of panel analysis.

\section{Lazarsfeld's second sabbatical at the Sorbonne in 1967/1968}

Lazarsfeld's second sabbatical at the Sorbonne in Paris was in the 1967/1968 academic year. This is confirmed, for example, by Elisabeth Noelle-Neumann [2001] and Raymond Boudon [1993: 5]. Around that time he was working on methodological issues and was completing his monograph on latent structure analysis, along with a shorter text - his entry on 'Survey Analysis: The Analysis of Attribute Data' in an encyclopaedia prepared at that time. He was thus primarily focusing on the subject of the multidimensional analysis of classificatory data. He gave lectures in seminars 'for PhD students' on this advanced method of data analysis. The second subject that he was devoting himself to at this time was work on an entry for the same international encyclopaedia. In the winter of 1967/1968 he completed a study together with David Landau on Adolph Quételet, whom Lazarsfeld considered to be the founder of the branch of sociology that Lazarsfeld and his methodological school were developing. This subject became a link connecting him to the Sorbonne, where he supervised doctoral students working on similar topics for many years.

In the spring of 1968 the situation at the university changed. It was significantly influenced by the student revolts. From around the middle of April classes at the Sorbonne were at first interrupted and then suspended following student protests, strikes, and even clashes in the streets with the police. Lazarsfeld reacted calmly to the situation. He continued to write articles and studies on methodology and, understandably, he also maintained contact in writing with his home workplace at Columbia University in New York, where Allen Barton was standing in for him as a reliable substitute in the role of director of BASR and Robert K. Merton was serving as his deputy in many other ways.

Reports from the United States were no more encouraging than the view of the student demonstrations in Paris from up close. BASR organised a representative survey in which Allen Barton and others, such as Stephen Cole and Hannelore Adamsons, surveyed the attitudes of students and teachers at Columbia University in May 1968 during the strikes by American students in New York [Barton 1968]. Allen Barton wrote an article on this titled 'The Columbia Crisis: Campus, Vietnam, and the Ghetto', in which he described the full story of student unrest in detail. The students were protesting university bureaucracy, the planned construction of a sports venue on the territory of a park that was a part of 
Harlem, and the war in Vietnam. His article offered a comparison of the attitudes of students and teachers at Columbia University and a comparison of their attitudes at the start of the conflict with the greater or lesser support of the general student strike that took place after police intervention on the Columbia campus. The situation in New York was comparable to that in Paris and it also had an influence on Lazarsfeld's sabbatical in Paris. Let's try to sum up at least some basic data from the article by Allen Barton. On Tuesday, 23 April 1968, a group of radical students at Columbia University who were part of an organisation called Students for a Democratic Society (SDS) occupied important areas of the university's administrative building. They '... occupied President Kirk's office, searched his files, and began copying correspondence that interested them' [ibid.: 334]. During the rest of this week: '...intensive negotiations and discussions followed ... The administration called on all concerned to clear the campus buildings ...' [ibid.]. Then came crucial moments: 'By the following Monday ... the administration requested the New York City police to clear the buildings. About midnight a force of over 1,000 police moved into the occupied buildings. ... After several hours all the buildings had been cleared and the students, a number with minor wounds, were taken to the police stations and booked.' [ibid.] And as a consequence or follow-up to these public affairs: 'A general student strike was called, which was respected by most faculty and students ...' [ibid.]. The strike lasted until the end of the spring semester of 1968.

What was Lazarsfeld working on in Paris when the student protests were taking place at Columbia University in New York? By chance we happen to have information about this from an eyewitness, as Elisabeth Noelle-Neumann met Paul Lazarsfeld in Paris at the Sorbonne at the very time that students were revolting in Paris and New York [Noelle-Neumann 2001]. She wrote that Lazarsfeld felt good in Paris, he was relaxed and at ease. Even though Paris was full of revolting students, he moved around confidently and seemed quite at home. He tended to be greeted by most students. " Don't be frightened," Lazarsfeld told me "I'll show you the way." He pulled me into the Sorbonne, where he was greeted with "hellos" by the students in the hallways. ... We strolled through the lecture halls. Lazarsfeld was at home.' [ibid.: 315] Noelle-Neumann described the results of her first-hand observations and the course of a conversation she had one day in Paris as follows: 'In reality, he had to use his time wisely. So, after two hours, we returned to the American House, where he was staying. ... He was working on a major essay that he later entitled, "An Episode in the History of Social Research: A Memoir." ... He told me he intended to do two things in the essay. First, he wanted to describe the spread of social research institutes at American universities and, secondly, the evolution of a new research approach that was becoming increasingly prevalent at U.S. universities.' [Noelle-Neumann 2001: 315] We know that during the second part of this stay in Paris Lazarsfeld wrote his memoirs.

At the end of the article quoted above, Elisabeth Noelle-Neumann revisited a memory from Paris and described how there was sudden shift in the situation: 'Returning to the American House in 1968: right while Lazarsfeld was dictat- 
ing, urgent messages arrived from New York, telegrams requesting that he return at once - the students demanded his immediate return. The only way to avoid serious disturbances on the campus was for him to come back immediately. He stopped working on his manuscript and departed for the United States.' [ibid.: 319-320] Noelle-Neumann did not indicate the exact date on which she met Lazarsfeld at the Sorbonne and she was unable to verify whether he did leave at that time for the United States. Nevertheless, the events in both Paris and New York significantly impacted his work in the spring of 1968 and his teaching at the Sorbonne in the spring semester of 1968.

\section{Lazarsfeld's French honours}

At the close of this paper devoted to Lazarsfeld's cooperative ties with France and French sociologists, it is also important to mention that he received official recognition for his life's work from the Sorbonne, which awarded him an honorary doctorate in 1972. When he died four years later, his closest colleagues in France did not wait for the next issue of some sociological journal to come out and on the day immediately after his death began paying their respects in the media to Lazarsfeld, who was a known public figure in France. His biographer David Sills [1987: 272] wrote on this: 'He received honorary degrees from Chicago and Yeshiva universities in 1966, from Columbia in 1970, from Vienna in 1971, and from the Sorbonne in 1972, the first American sociologist ever so honored.' And this same biographer provides what is perhaps even more important evidence of how much Lazarsfeld was valued by his colleagues in France: 'He visited Paris frequently, and Reid Hall at the Sorbonne became almost his second home. He invited a number of Europeans to spend a year at Columbia, and in this way enriched sociology on both sides of the Atlantic. When he died, Raymond Boudon and Jean Stoetzel wrote memorial articles for the Paris press, and almost every sociological journal in Western Europe published an obituary. ${ }^{\prime 18}$ [Sills 1979: 418-419]

\section{Conclusion}

The aim of this paper was to add to and go beyond the texts that have been published to date highlighting the important influence that the Columbia School of Sociology had in post-war Europe. We focused here on France and described Lazarsfeld's coordinating activities and collaborative work and the actions of specific researchers working to promote at the Sorbonne the model of social research that had been developed over many years at Columbia University in New York.

\footnotetext{
${ }_{18}$ We can read the reprint of Boudon's memorial article from Le Monde as a document in a representative French sociological journal [Boudon 1992].
} 
Franco-American cooperation had support from prominent foundations and national scientific associations on both sides of the Atlantic as well as from the social sciences section of UNESCO.

The article primarily tracked the scientific, teaching, and organisational activities that Paul Lazarsfeld, Jean Stoetzel, and Raymond Boudon engaged in to promote the methodology of empirical social research in France. Their colleagues and doctoral students at the Sorbonne in Paris and Columbia University in New York also performed a great deal of work in this area. Everything was done with the support of the French Fondation Maison des Sciences de l'Homme, the financial support of the Rockefeller Foundation and the Fulbright Exchange Programme in the United States, and the backing of UNESCO. However, the most important factor was the actions of specific individuals, scholars, organisers, students, publishers, and other figures who were involved in these processes. Alain Chenu wrote [2001: 106]: 'French and US contributions to a meeting in Lazarsfeld's memory were published in Paris [Lautman and Lécuyer 1998] testifying to his long-term influence' in France.

HyNeK JeRABeK is a professor of sociology at the Faculty of Social Sciences of Charles University in Prague. He is the author of numerous works on sociological methodology and on the history of empirical social research. His most recent book was Paul Lazarsfeld and the Origins of Communications Research, which was published by Routledge in 2017. He has published work in English in Ethnic and Racial Studies, Sociológia, and Czech Sociological Review, and he wrote the entry on empirical social research for the International Encyclopedia of the Social and Behavioral Sciences.

\section{References}

Averbeck, S. 2008. 'Comparative History of Communication Studies: France and Germany.' The Open Communication Journal 2: 1-13, https://doi.org/10.2174/1874916X00802010001.

Barton, A. H. 1968. 'The Columbia Crisis: Campus, Vietnam, and the Ghetto.' Public Opinion Quarterly 32 (3): 333-351, https://doi.org/10.1086/267619.

Barton, A. H. 1982. 'Paul Lazarsfeld and the Invention of the University Institute for Applied Social Research.' Pp. 17-82 in Organizing for Social Research, edited by B. Holzner and J. Nehnevajsa. Cambridge, MA: Schenkman Publ. Co.

Boudon, R. 1992. (1976) 'In memoriam: Un marginal devenu un classique: P. Lazarsfeld.' Le Monde. Reprinted in Sociologie, edited by Van Meter. Paris: Larousse.

Boudon, R. 1993. 'Introduction.' Pp. 1-29 in On Social Research and Its Language, by P. F. Lazarsfeld, edited by R. Boudon. Chicago, IL, and London: University of Chicago Press.

Boudon, R. and P. F. Lazarsfeld (eds). 1965. Le vocabulaire des sciences sociales, concepts et indices. Paris and The Hague: Mouton \& Co, https://doi.org/10.1515/9783111586809. 
Boudon, R. and P. F. Lazarsfeld (eds). 1966. L'analyse empirique de la causalité. Paris and The Hague: Mouton \& Co., https://doi.org/10.1515/9783110899252.

Bourdieu, P. 1982. 'Préface'. Pp. i-ii in Les chômeurs de Marienthal, by P. Lazarsfeld, M. Jahoda and H. Zeisel. Paris: Minuit.

Calhoun, C. (ed.) 2007. Sociology in America. A History. Chicago, IL, and London: Chicago University Press.

Chazel, F., R. Boudon and P. F. Lazarsfeld (eds). 1970. L'analyse des processus sociaux. Paris and The Hague: Mouton \& Co., https:// doi.org/10.1515/9783111541624.

Chenu, A. 2001. 'US Sociology through the Mirror of French Translation.' Contemporary Sociology 30 (2): 105-109, https://doi.org/10.2307/2655366.

Coleman, J. 1982. 'Introduction' Pp. 1-8 in The Varied Sociology of Paul F. Lazarsfeld, edited by P. L. Kendall. New York: Columbia University Press.

Gemelli, G. 1998. 'Paul Lazarsfeld et la France au milieu des années soixante.' Pp. 465-497 in Paul Lazarsfeld (1901-1976), edited by J. Lautman and B.-P. Lécuyer. Paris: L'Harmattan.

Jerabek, H. 2012. 'Six Examples of Collaboration between Paul F. Lazarsfeld and Robert K. Merton.' Pp. 2-27 in The Early Days of Survey Research and Their Importance Today, edited by H. Haas, H. Jerabek and T. Petersen. Vienna: Braumüller.

Jeřábek, H. 2021. 'Paul Lazarsfeld's Contributions to the History of Empirical Social Research.' Theory of Science. Retrieved 9 December 2021 (https://teorievedy.flu.cas.cz/index.php/tv/article/view/508), https://doi.org/10.46938/tv.2021.508.

Lautman, J. and B.-P. Lécuyer (eds). 1998. Paul Lazarsfeld (1901-1976). La sociologie de Vienne à New York. Paris: L'Harmattan.

Lazarsfeld, P. F. 1957. 'Public Opinion and the Classical Tradition.' Public Opinion Quarterly 21 (1): 39-53, https:// doi.org/10.1086/266685.

Lazarsfeld, P. F. 1970. Philosophie des sciences sociales, edited and with an introduction by Raymond Boudon. Paris: Gallimard.

Lazarsfeld, P. F. (1961) 1982a. 'Notes on the History of Quantification in Sociology Trends, Sources, and Problems.' Pp. 97-170 in The Varied Sociology of Paul F. Lazarsfeld, edited by P. L. Kendall. New York: Columbia University Press.

Lazarsfeld, P. F. (1968) 1982b. 'An Episode in the History of Social Research: A Memoir.' Pp. 11-73 in The Varied Sociology of Paul F. Lazarsfeld, edited by P. L. Kendall. New York: Columbia University Press.

Lazarsfeld, P. F. and R. K. Merton. (1954) 1982. 'Friendship as Social Process: A Substantive and Methodological Analysis.' Pp. 298-348 in The Varied Sociology of Paul F. Lazarsfeld, edited by P. L. Kendall. New York: Columbia University Press.

Lazarsfeld, P. F. and M. Rosenberg (eds). 1955. The Language of Social Research. A Reader in the Methodology of Social Research. New York: The Free Press.

Lazarsfeld, P. F., A. K. Passanella and M. Rosenberg (eds). 1972. Continuities in the Language of Social Research. New York: Free Press.

Lécuyer, B.-P. 2002. 'Un grande figure francophile de la sociologie empirique, quantitative et mathématique et de son étude historique: Paul Lazarsfeld (1901-1976).' Mathématiques et sciences humaines 40 (157): 49-104, https://doi.org/10.4000/msh.2865.

Neurath, P. M. 1979. Paul Lazarsfeld 1901-1976 und die Entwicklung der empirischen Sozialforschung. Vienna: Universität Wien, Institut für Soziologie der Sozial- und Wirtschaftswissenschaftlichen Fakultät.

Noelle-Neumann, E. 2001. 'My Friend, Paul F. Lazarsfeld.' International Journal of Public Opinion Research 13 (3): 315-321, https://doi.org/10.1093/ijpor/13.3.315.

Pollak, M. 1980. 'Paul F. Lazarsfeld: A Sociointellectual Biography.' Knowledge: Creation, Diffusion, Utilization 2 (2): 157-177, https://doi.org/10.1177/107554708000200201. 
Raymond Boudon. 2014. Revista de Sociologia 99 (4): 421-629, https://doi.org/10.5565/rev/papers.2158.

Sills, D. 1979. 'Lazarsfeld, Paul F.' Pp. 411-427 in International Encyclopedia of the Social Sciences. Biographical Supplement Vol. 18. New York and London: The Free Press.

Sills, D. 1987. 'Paul F. Lazarsfeld 1901-1976. A Biographical Memoir by David Sills.' Pp. 251-282 in Biographical Memoirs 56. Washington, DC: The National Academy Press.

Steinmetz, G. 2007. 'American Sociology before and after World War II: The (Temporary) Settling of a Disciplinary Field.' Pp. 314-366 in Sociology in America. A History, edited by C. Calhoun. Chicago, IL, and London: Chicago University Press, https://doi.org/10.7208/chicago/9780226090962.003.0009.

Stoetzel, J. 1953. 'The Contribution of Public Opinion Research Techniques to Social Anthropology.' International Social Science Bulletin 5 (3): 494-503.

Thue, F. W. 2006. In Quest of a Democratic Social Order. The Americanization of Norwegian Social Scholarship 1918-1970. Oslo: University of Oslo.

Turner, S. P. and J. H. Turner. 1990. The Impossible Science. An Institutional Analysis of American Sociology. Newbury Park, CA: Sage.

Wikipedia. 2021. 'Jean Stoetzel.' Last modified 10 September 2021. Retrieved 24 October 2021 (https://fr.wikipedia.org/wiki/Jean_Stoetzel). 